\title{
$\mathrm{C} 2 \mathrm{C} 12$ 골격근 세포에서 백출의 분화 조절 효능
}

\author{
송미영
}

동국대학교 한의과대학 한방재활의학교실

\section{Effect of Root of Atractylodes macrocephala Koidzumi on Myogenesis in C2C12 Cells}

\author{
Mi-Young Song \\ Department of Rehabilitation Medicine of Korean Medicine, College of Korean Medicine, Dongguk University
}

Received: May 20, 2015

Revised: June 8, 2015

Accepted: June 8, 2015
Correspondence to: Mi-Young Song Department of Rehabilitation Medicine of Korean Medicine, College of Korean Medicine, Dongguk University, 123 Dongdae-ro, Gyeongju 780-714, Korea

Tel: +82-54-770-1264

Fax: +82-54-770-1200

E-mail: miyoungsong@dongguk.ac.kr

Copyright $@ 2015$ by The Society of Korean

Medicine for Obesity Research
Objective: Skeletal muscle is a crucial tissue from the perspectives of mitochondrial dysfunction and insulin resistance, it is formed by myogenesis which is dynamic multistep process to be myotubes. The authors could found that root of Atractylodes macrocephala Koidzumi (Atractylodis Rhizoma Alba, ARA) enhanced glucose and lipid metabolism in C2C12 myotubes via mitochondrial regulation. However its action in myogenesis process is not known. The aim of this work was the study of ARA on proliferation, differentiation and hypertrophy in C2C12 cells.

Methods: To study proliferation phase, cells were incubated in growth medium with or without ARA $(0.2$ or $1.0 \mathrm{mg} / \mathrm{ml})$ for 24 hours. To examine differentiation, at $70 \%$ confluence, cells were transferred in differentiation medium both with/without ARA $(0.2$ or $1.0 \mathrm{mg} / \mathrm{ml})$ for 96 hours. And after 72 hours of differentiation, cells were treated with or without ARA $(0.2$ or $1.0 \mathrm{mg} / \mathrm{ml})$ for 24 hours, the genesis of hypertrophy in myotubes were analyzed.

Results: In proliferation phase, ARA could make difference in morphologic examination. In differentiation phase, it also made morphologic difference furthermore ARA $(1.0 \mathrm{mg} / \mathrm{ml})$ increased mRNA expressions of Myogenic regulatory factors and muscle-specific proteins synthesis. In late differentiation, ARA induced hypertrophic morphological changes in neo-formed myotubes.

Conclusions: ARA might control cell cycle promoting myogenesis and hypertrophy in $\mathrm{C} 2 \mathrm{C} 12$ cells.

Key Words: Atractylodes macrocephala Koidzumi, Myogenesis, Prolireation, Differentiation, Hypertrophy, C2C12

\section{서 론}

최근 비만 및 관련 질환의 연구에 있어서 골격근이 중요 하게 다뤄지고 있다. 골격근은 인슐린 저항성의 주된 원인 으로 인슐린 저항성 조절을 위한 주요 기관이며 ${ }^{1-3)}$, 동시에 에너지 생산, 열생산의 작용을 통한 생체에너지 조절의 핵 심 기관이단)

골격근 세포는 근육분화(myogenesis) 과정을 통해 myoblast에서 myotube로 성숙됨에 따라 세포의 형태가 빠른 속도로 변화한다. 증식기에는 단핵 상태로 원형에서 크기가
커지면서 점차 방추형으로 변하며, 분화기에는 세포들이 점 차 더 길이지면서 주위의 여러 개의 세포들이 서로 융합되 어 관 형태의 다핵 세포인 myotube로 분화된다. 그리고 분 화 종료 후 myotube는 직경과 길이를 증대시켜 근육을 비 대시켜 나간다 ${ }^{5,6)}$. 근육 분화는 $\mathrm{MyOD}, \mathrm{MRF} 5$ 등과 같은 myogenic regulatory factors (MRFs)에 의해서 조절되며 ${ }^{7,8)}$, 또한 분화후기에는 myotube의 주요 구조 단백질인 myosin heavy chain (MHC)의 발현량이 증가하는 것으로 알려져 있다 ${ }^{9)}$. 따라서 $\mathrm{MRF}$ 및 $\mathrm{MHC}$ 를 근육 분화의 표지 인자로 사용하여 이들의 발현량 측정을 통해 근육 분화도를 확인할 
수 있다 ${ }^{10)}$. 그리고 분화 종료 후에는 단백질 합성 경로를 통 해 융합된 근관세포들에서 근관의 직경이 커지고 길이가 길 어지게 되는 근육비대(muscle hypertrophy) 과정을 통해 근육의 크기를 증가시키게 된다 ${ }^{11,12)}$.

백출(Atractylodis Rhizoma Alba, ARA)은 고지방 섭취 로 유발된 비만형 동물모델에서 체중감량, 지질개선 효과 ${ }^{13)}$ 및 3T3-L1 지방세포에서 인슐린 조절 경로를 활성화시키 는 효능을 나타내어 ${ }^{14}$ 항비만, 인슐린 저항성 개선 효과가 기대되는 약물이다. 본 연구자는 선행연구에서 $\mathrm{C} 2 \mathrm{C} 12$ 골 격근 배양 모델 실험에서 백출이 에너지 조절 및 미토콘드 리아 기능 조절과 관련된 adenosine monophosphateactivated protein kinase (AMPK), sirtuin (SIRT) 1 및 peroxisome proliferator-activated receptor gamma $\mathrm{CO}^{-}$ activator 1 alpha (PGC1 $\alpha$ )를 활성화시키는 것을 확인하였 다(unpublished). 골격근 조절 작용에 대한 백출의 보다 구 체적인 효능 평가를 위해서 근육 분화 조절과 관련된 연구 역시 필요하다. 이에 본 연구에서는 $\mathrm{C} 2 \mathrm{C} 12$ 골격근 세포 배 양 모델에서 증식기, 분화기 및 분화후기로 나누어 각각 단 계별로 백출의 조절 효능을 평가하고자 하였다.

\section{재료 및 방법}

\section{1. 약재}

백출은 (주)광명당제약(Ulsan, Korea)으로부터 표준약재 를 구입하여 동국대학교 한의과대학 본초학교실에서 감별 한 후 정선하여 시료로 사용하였다. 백출 $200 \mathrm{~g}$ 에 정제수 2 $\mathrm{L}$ 를 가하여 열탕 추출기에서 3시간씩 2회 가열하여 얻은 추출물을 여과지(Whatman NO. 1; Sigma-Aldrich, St. Louis, MO, USA)로 여과한 후 회전식 감압농축기로 감압 농축하여 동결 건조하여서 물 추출물을 제조하였다. 이때 수득률은 26\%였다.

\section{2. 세포배양}

마우스 유래 C2C12 세포주는 American Type Culture Collection (ATCC, CRL-1772; Manassas, VA, USA)으 로부터 분양받아 사용하였으며, $37^{\circ} \mathrm{C} 5 \% \mathrm{CO}_{2}$ 상태에서 배 양하였다. 분화 전 세포의 증식기에는 penicillin/streptomycin $1 \%$ 를 함유한 고농도 포도당 Dulbecco's modified

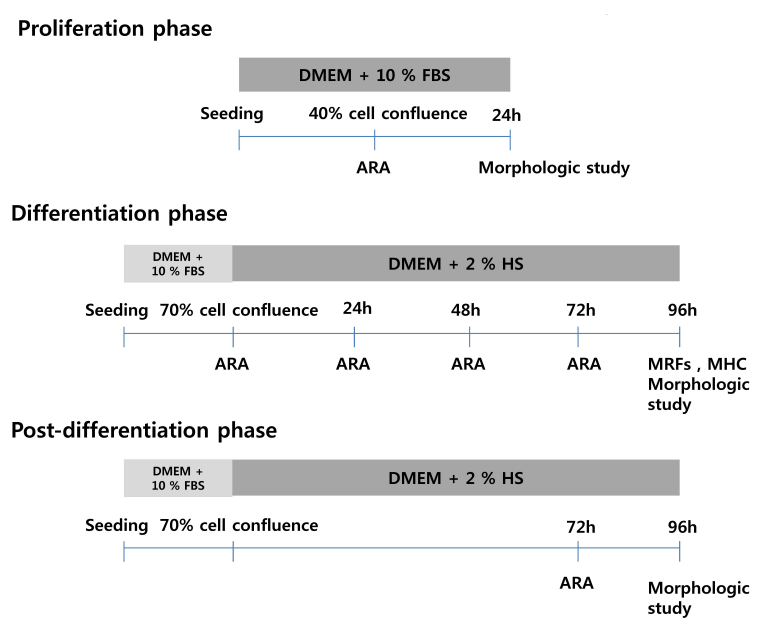

Fig. 1. Description of each experimental phase of the study protocol. DMEM: Dulbecco's modified Eagle's medium, FBS: fetal bovine serum, ARA: Atractylodis Rhizoma Alba, HS: horse serum, MRF: myogenic regulatory factor, MHC: myosin heavy chain.

Eagle's medium (DMEM)과 10\% fetal bovine serum (FBS) 배지를 사용하였으며, 분화 유도 시에는 $\mathrm{FBS}$ 를 $2 \%$ horse serum (HS)으로 변경하였다. 약물 처치 시기 및 횟수 는 Montesano 등 ${ }^{10}$ 의 실험 방법을 참고로 하여 실험 목적 에 따라 달리하였다(Fig. 1).

\section{3. 세포독성평가}

C2C12에 대한 시료의 세포 생존능 평가는 thiazoly blue tetrazolium bromid (MTT)를 이용하여 측정하였다. C2C12 세포는 실험 전날 $1 \times 10^{6}$ cells $/ \mathrm{ml}$ 농도로 96-well plate에 seeding하고, 백출 추출물을 $0.1,0.2,0.5$ 및 $1.0 \mathrm{mg} / \mathrm{ml}$ 를 처리하여 24시간 동안 배양하였다. 그 후 배양액을 모두 버 리고 DMEM에 녹인 $5 \mathrm{mg} / \mathrm{ml}$ MTT (Sigma, St. Louis, $\mathrm{MO}, \mathrm{USA}$ )를 $100 \mu \mathrm{l}$ 씩 각 well에 처리하여 알루미늄 호일 로 차광시킨 후 2 시간 동안 같은 조건에서 배양하였다. 배 양액을 모두 제거한 후 demethyl sulfoxide $100 \mathrm{ml}$ 를 처리 하고 2시간 방치 후 Microplate Reader (Molecular Devices, Sunnyvale, CA, USA)를 이용하여 $540 \mathrm{~nm}$ 에서 흡광도를 측정하였다.

\section{4. 형태 관찰}

디지털 카메라 시스템(Olympus C7070; Olympus, Tokyo, Japan)이 장착된 광학현미경(Olympus CKX41; Olympus) 
을 이용하여 세포의 형태를 관찰하였다. 또한 myotube의 길이, 직경 측정은 Yeh 등 ${ }^{15)}$ 의 실험 방법을 참고하여, 군별 로 각각 3 개씩 배양하고, 각각의 well을 9 개의 사각형으로 등분하여 각 구역당 10 개 myotube의 직선 길이 및 직경을 Leica application suite version 4.2 (Leica Microsystems, Heerbrugg, Swizerland)를 이용하여 측정하고 평균값을 산 출하였다.

\section{Real time polymerase chain reaction (PCR) analysis}

$\mathrm{MyoD}, \mathrm{MRF} 5$ 및 $\mathrm{MHC}$ 의 mRNA 발현량을 측정하기 위해 reverse transcription-PCR을 수행하였다. 각 세포를 수거하여 5,000 rpm에서 5분간 원심 분리한 후 TRIzol 시 약을 이용하여 total RNA를 분리하였다. 분리된 RNA에 oligo-(dT) primer와 Improm-II ${ }^{\mathrm{TM}}$ reverse transcriptase 를 넣어 $25^{\circ} \mathrm{C}$ 에서 10 분, $42^{\circ} \mathrm{C}$ 에서 60 분, $70^{\circ} \mathrm{C}$ 에서 15 분 조건으로 $\mathrm{mRNA}$ 로부터 $\mathrm{cDNA}$ 를 합성하였다. $\mathrm{PCR}$ 을 수행 하기 위해서 $\mathrm{mRNA}$ 로부터 합성된 $\mathrm{cDNA} 1 \mu \mathrm{g}$ 에 mouse MyoD primers [sense; 5'-CAA CGC CAT CCG CTA CA-3', antisense; 5'-GTC TGG GTT CCC TGT TCT GT-3'], mouse MRF 5 primers [sense; 5'-CGT AGA CGC CTG AAG AA-3', antisense; 5'-GCG ATA GAT AAG TCT GGA GC-3'], mouse MHC primers [sense; 5'-TGA ACT GGA GGG TGA GGT AG-3', antisense; 5'-TTC GGT CTT CTT CTG TCT GG -3']와 mouse GDPAH primers [sense; 5'-ATT CAA CGG CAC ACT CAA GG-3', antisense; 5'-CAG TGT AGC CCA AGA TGC CCT -3'] 및 10× PCR buffer $(10 \mathrm{mM}$ Tris-HCl, $\mathrm{pH}$ 8.3, $50 \mathrm{mM} \mathrm{KCl}, 0.1 \%$ Triton X-100), $250 \mu \mathrm{M}$ dNTP, $1 \mathrm{U}$ Tag polymerase 등을 혼합한 후 denaturation 을 위해 $94^{\circ} \mathrm{C}$ 에서 30 초, annealing을 위해 $55^{\circ} \mathrm{C} \sim 60^{\circ} \mathrm{C}$ 에 서 30 초 및 extension을 위해 $70^{\circ} \mathrm{C}$ 에서 60 초 조건에서 30 cycles을 수행하였다. PCR 반응물은 $\mathrm{EtBr}$ 이 포함된 $1 \%$ agarose gel을 이용하여 전기 영동한 후 ultraviolet lamp를 이용하여 확인하였으며, Image-J 프로그램(public domain) 을 이용하여 glyceraldehyde-3-phosphate dehydrogenase 에 대한 발현 비율로 표시하였다.

\section{6. 통계처리}

GraphPad Prism (GraphPad Software Inc., San Diego, $\mathrm{CA}, \mathrm{USA}$ )을 이용하여 통계처리하였다. 각 2회의 반복 실 험의 결과를 mean \pm standard errors of mean으로 나타내 고, analysis of variance (Tukey's test)를 사용하여 분석하 였으며, 통계적인 유의성은 P-value가 0.05 이하인 경우에 인정하였다.

\section{결 과}

\section{1. 세포생존율}

백출 물추출물이 $\mathrm{C} 2 \mathrm{C} 12$ 의 골격근 세포의 생존율에 미치 는 영향을 비교하였다. 24시간 동안 처리한 결과 모든 농도 에서 유의한 변화는 나타나지 않았다(Fig. 2).

\section{2. 증식기}

40\% confluence 상태에서 백출을 농도별로 24시간 처리 한 후 형태학적인 변화를 관찰하였다. 그 결과 대조군에서 보이는 증식기 myoblast 상태에서의 둥근 형태의 세포 모 양에 비해 백출 처치군에서 고농도일수록 보다 길어진 형태 의 myocyte로 성장하였음을 확인할 수 있었다(Fig. 3).

\section{3. 분화기}

$70 \%$ confluence 상태에서 $2 \% \mathrm{HS}$ 가 포함된 분화용 배지 로 교환한 후 24시간 간격으로 백출을 96시간 동안 처리하 였다. 형태학적인 변화에서는 백출 $1.0 \mathrm{mg} / \mathrm{ml}$ 군에서 분화 후기의 myotube의 형태를 보다 분명하게 나타낸 것을 확인 할 수 있었다(Fig. 4A). 또한 분화 표지인자로 MRFs 중

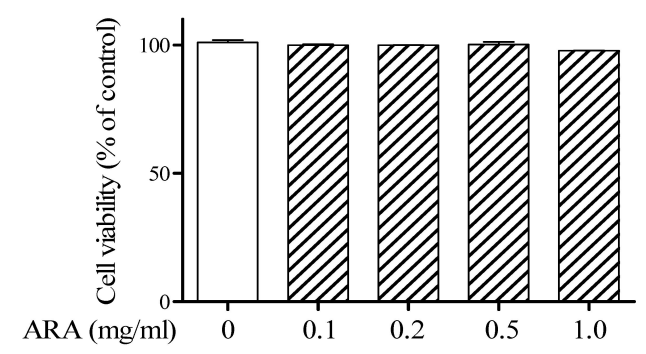

Fig. 2. Effect of Atractylodis Rhizoma Alba (ARA) on cell viability in C2C12 cells. Cells were incubated for 24 hours. Results are represented as mean \pm standard errors of mean. 
Control

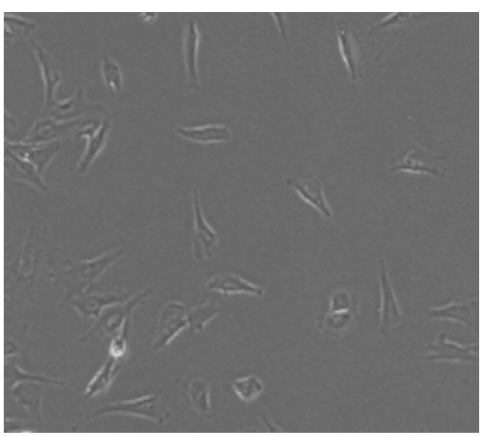

ARA $0.2 \mathrm{mg} / \mathrm{ml}$

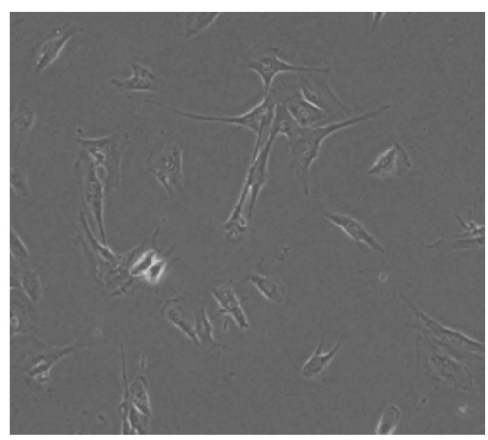

ARA $1.0 \mathrm{mg} / \mathrm{ml}$

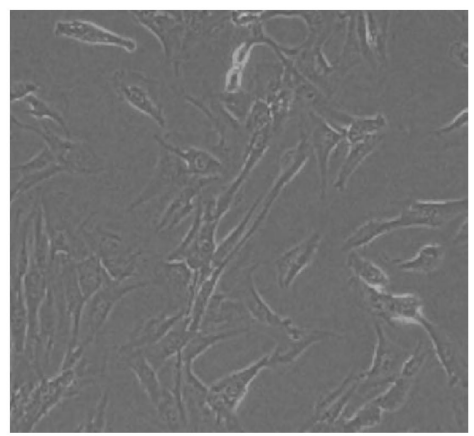

Fig. 3. Effect of Atractylodis Rhizoma Alba (ARA) in proliferation phase. C2C12 cells were maintained with Dulbecco's modified Eagle's medium containing $10 \%$ fetal bovine serum up to $40 \%$ conflunece, and then treated with or without ARA extract $(0.2$ or $1.0 \mathrm{mg} / \mathrm{ml})$. The images were captured using microscope $(\times 100)$.

A

Control

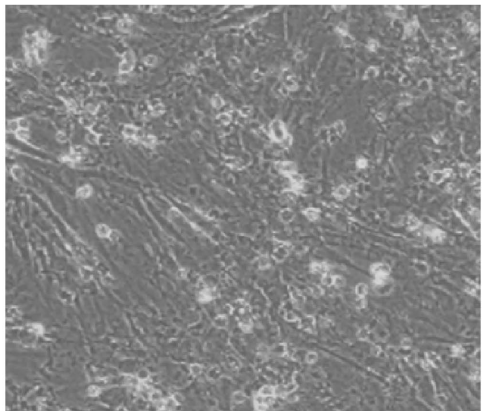

ARA $0.2 \mathrm{mg} / \mathrm{ml}$

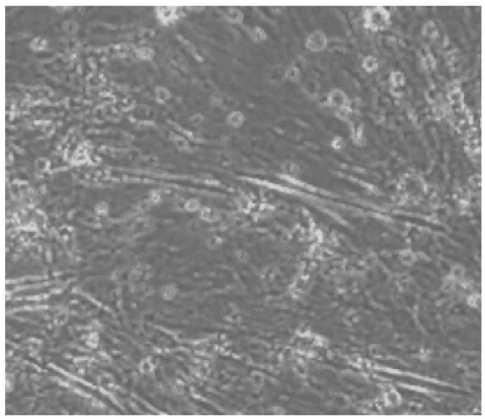

ARA $1.0 \mathrm{mg} / \mathrm{ml}$

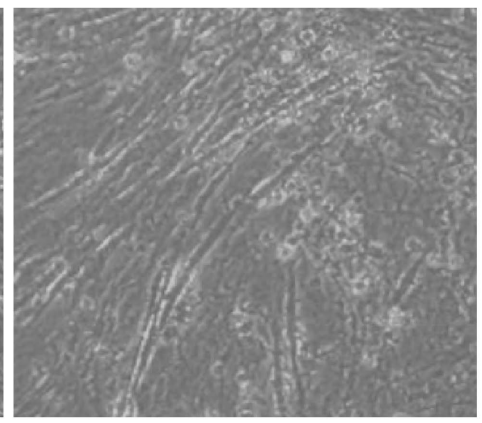

B
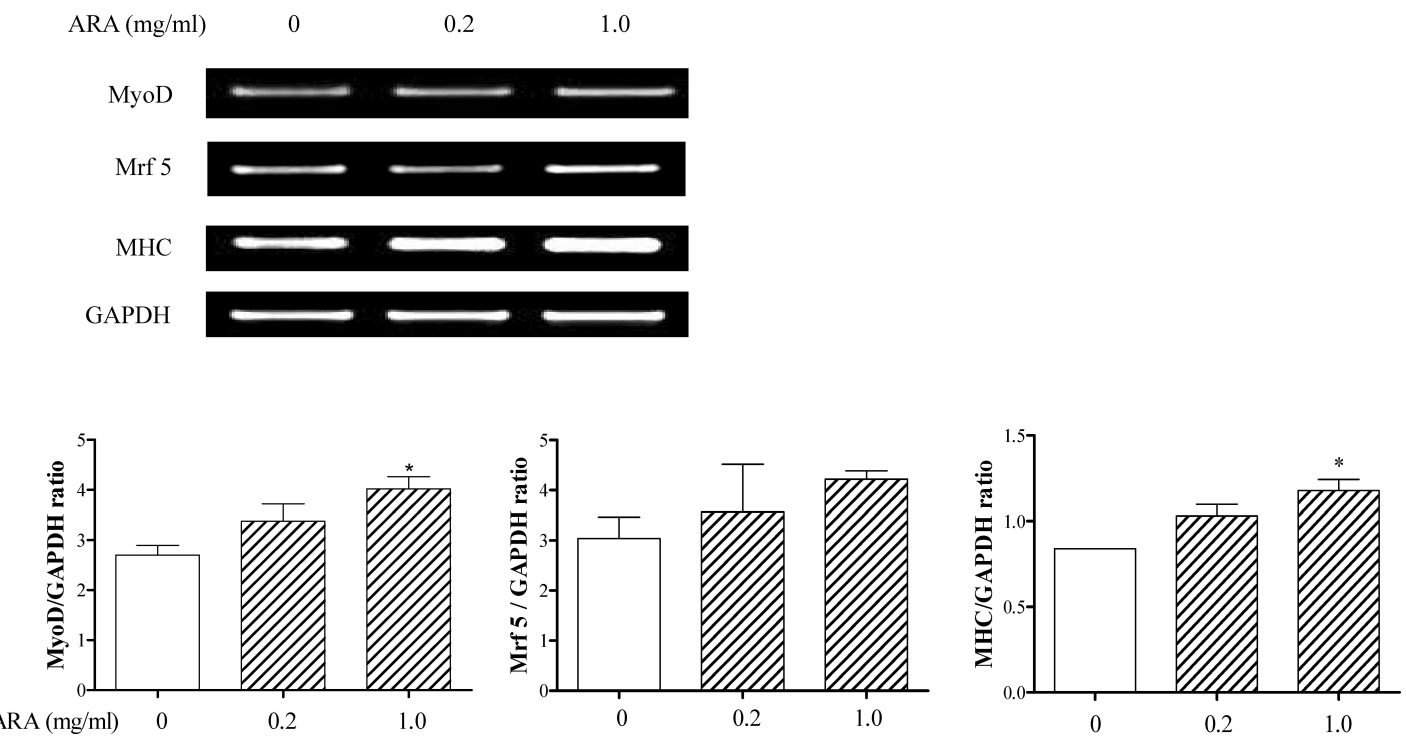

Fig. 4. Effect of Atractylodis Rhizoma Alba (ARA) in differentiation phase. C2C12 cells were maintained with Dulbecco's modified Eagle's medium containing $10 \%$ fetal bovine serum up to $70 \%$ confluence, and then medium was changed to $2 \%$ horse serum with or without ARA extract (0.2 or $1.0 \mathrm{mg} / \mathrm{ml}$ ) every 24 hours for 96 hours. (A) Morphological changes. The images were captured using microscope $(\times 100)$. (B) The mRNA expressions of MyoD, Mrf5 and myosin heavy chain $(\mathrm{MHC})$. Results are represented as means \pm standard errors of mean. GAPDH: glyceraldehyde-3-phosphate dehydrogenase. ${ }^{*} \mathrm{P}<0.05$ versus non-treated cells. 
$\mathrm{MyoD}, \mathrm{Mrf} 5$ 및 MHC의 mRNA 발현량을 분석하였는데, 백출 $1.0 \mathrm{mg} / \mathrm{ml}$ 에서 $\mathrm{MyoD}$, Mrf 5의 mRNA 발현량이 대 조군에 비해서 증가하였으며, 분화후기의 근관 세포 형성도 를 보다 특이적으로 나타낼 수 있는 MHC의 mRNA 발현 량 역시 백출 $1.0 \mathrm{mg} / \mathrm{ml}$ 에서 대조군에 비해서 유의하게 증 가한 것으로 나타났다 $(\mathrm{P}<0.05$; Fig. 4B).

\section{4. 분화후기}

$70 \%$ confluence 상태에서 72시간 동안 분화용 배지를 교환하면서 분화시킨 후, 24시간 동안 약물을 처리하여 백 출이 근관세포의 비대에 대한 효능을 형태학적인 관찰을 통 해 평가하였다. 근관세포의 길이 및 직경 모두 백출 1.0 $\mathrm{mg} / \mathrm{ml}$ 에서 대조군에 비해 유의하게 증가하였다 $(\mathrm{P}<0.01$; Fig. 5).

\section{고 찰}

비만은 골격근의 유지와 재생에도 영향을 주는데, 비만 으로 인해서 근육내 지방산, diacylglycerols, ceramides 및 염증유발 cytokine이 늘어나고 이들이 골격근 세포의 증식, 분화 및 성장 과정에서 각각 영향을 주어 근육의 재생을 지 연시키게 된다 ${ }^{16)}$. 또한 근육량이 부족해질수록 지방 조직의 산화가 감소하고, 염증이 유발되며, 인슐린 저항성이 증가 하는 것으로 알려져 있으므로 비만 치료 시 골격근을 동시 에 고려하는 것이 중요하다 ${ }^{17)}$.

본 연구에서는 $\mathrm{C} 2 \mathrm{C} 12$ 세포의 증식, 분화 및 비대로 이어 지는 분화, 성숙의 전 과정을 형태학인 관찰 및 분화 표지
인자의 발현량 측정을 통해 평가하였다. 형태학적인 관찰에 서 백출이 대조군에 비해서 눈에 띄는 형태학적인 변화를 일으키는 것을 확인할 수 있었다. 증식기에는 약물 투여 24 시간 뒤 원형 상태의 대조군에 비해서 방추형의 상태로 보 다 빠르게 증식하였으며, 분화기에는 세포 융합 및 $\mathrm{myo}^{-}$ tube 형성이 보다 두드러지게 관찰되었다. 또한 분화 후기 myotube의 형태를 길이와 직경 측정을 통해 비교하였을 때, 저농도의 $0.2 \mathrm{mg} / \mathrm{ml}$ 에서는 대조군과 차이가 없었지만, 백출 $1.0 \mathrm{mg} / \mathrm{ml}$ 에서는 유의하게 증가한 것으로 나타났다.

한편, 분화표지인자로 본 연구에서는 $\mathrm{MRFS}$ 와 $\mathrm{MHC}$ 를 이용하여 발현량 측정을 통해 분화도를 평가하였고 유의한 결과를 얻을 수 있었다. MRFs는 $\mathrm{MyoD}$, myogenin, $\mathrm{MRF}$ 4 및 MRF 5가 있으며, 이들은 myoblast의 융합을 촉진시 키는 공통 작용을 한다 ${ }^{18)}$. 본 연구에서는 그 중 $\mathrm{MyoD}$, $\mathrm{MRF} 5^{19)}$ 의 mRNA 발현량을 측정하였으며, 백출의 농도 가 높을수록 발현량이 증가하는 것으로 나타났다. 또한 myotube의 주된 구조 단백질인 $\mathrm{MHC}$ 의 발현량을 측정하 였는데, $\mathrm{MyoD}, \mathrm{MRF} 5$ 에 비해서 $\mathrm{MHC}$ 가 보다 특이적으 로 분화 후기의 상태를 평가할 수 있는 장점이 있다 ${ }^{10)}$. $\mathrm{MHC}$ 의 mRNA 발현량 역시 농도가 높을수록 증가하였으 며, 백출 $1.0 \mathrm{mg} / \mathrm{ml}$ 에서 유의하게 증가한 것으로 나타났다.

골격근에서 백출의 작용은 연구가 발표된 바 없으며, 본 연구자는 선행연구에서 $\mathrm{C} 2 \mathrm{C} 12$ myotube에서 백출 1.0 $\mathrm{mg} / \mathrm{ml}$ 가 에너지 조절 및 미토콘드리아 조절과 관련한 $\mathrm{AMPK}, \mathrm{SIRT} 1$ 을 유의하게 활성화시켰으며, PGC1 $\alpha$ 를 비 롯한 미토콘드리아 생합성 조절 인자의 발현량을 증가시키 는 것을 확인할 수 있었다. 또한 미토콘드리아의 에너지 조

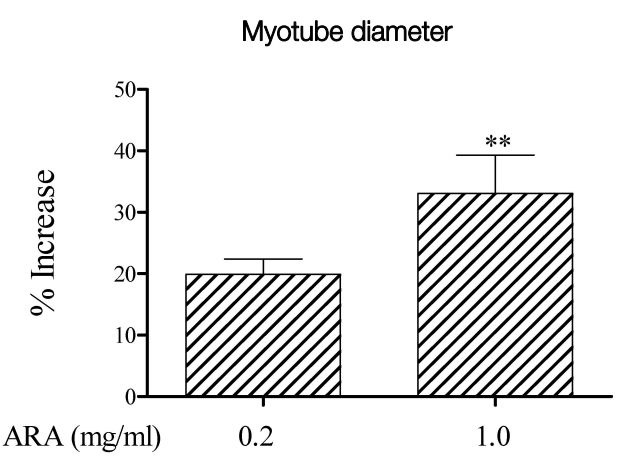

Fig. 5. Effect of Atractylodis Rhizoma Alba (ARA) in post-differentiation phase. After 72 hours of differentiation, cells were treated with or without ARA $(0.2$ or $1.0 \mathrm{mg} / \mathrm{ml})$ for 24 hours. Increment in length and diameter of ARA-treated cells compared to non-treated cells. Results are represented as mean \pm standard error of mean. ${ }^{* *} \mathrm{P}<0.01$ versus non-treated cells. 
절과 관련한 당과 지방산 대사 또한 백출 $1.0 \mathrm{mg} / \mathrm{ml}$ 에서 유의하게 증가하는 것을 관찰하였다(unpulished). 미토콘 드리아는 골격근 세포의 분화에도 중요하게 작용하는데, 미 토콘드리아 기능이 저하될수록 세포 분화 및 재생산이 감소 되는 것으로 알려져 있으며, 근육분화가 증가할수록 PGC1 $\alpha$, $\mathrm{NRF1}$, Tfam의 발현량이 증가하게 된다 ${ }^{20,21)}$. 또한 AMPK 와 SIRT1 역시 근육 분화를 증가시키는 것으로 알려져 있 다 ${ }^{22,23)}$. 따라서 본 연구의 결과는 미토콘드리아 조절 효능 과 관련한 본 연구자의 선행 연구 결과와도 일치하는 내용 이다.

보다 엄격한 효과 검증을 의해서는 양성 대조군의 설정, 단백질 합성에 관여하는 insulin receptor signaling pathway 등에 대한 작용 기전의 규명 ${ }^{11)}$ 및 $\mathrm{p} 120, \mathrm{~N}$-Cadherin 등의 골격근 구조 단백질 ${ }^{24)}$ 도 같이 평가하는 것이 필요하 다. 본 연구를 통해 백출이 골격근 $\mathrm{C} 2 \mathrm{C} 12$ 세포 분화를 증 가시킴을 확인할 수 있었으며, 추후 후속 보완 연구를 통해 관련 기전을 보다 명확하게 규명할 필요가 있다.

\section{감사의 글}

이 논문은 2015년도 정부(미래창조과학부)의 재원으로 한국연구재단의 지원을 받아 수행된 기초연구사업임(No. 2014R1A1A1003758).

\section{References}

1. Kelley DE, He J, Menshikova EV, Ritov VB. Dysfunction of mitochondria in human skeletal muscle in type 2 diabetes. Diabetes. 2002 ; 51(10) : 2944-50.

2. Lowell BB, Shulman GI. Mitochondrial dysfunction and type 2 diabetes. Science. 2005 ; 307(5708) : 384-7.

3. DeFronzo RA, Tripathy D. Skeletal muscle insulin resistance is the primary defect in type 2 diabetes. Diabetes Care. 2009 ; 32(suppl 2) : S157-S63.

4. Tseng YH, Cypess AM, Kahn CR. Cellular bioenergetics as a target for obesity therapy. Nat Rev Drug Discov. 2010 ; 9(6) : 465-82.

5. Burattini S, Ferri P, Battistelli M, Curci R, Luchetti F, Falcieri E. C2C12 murine myoblasts as a model of skeletal muscle development: morpho-functional characterization. Eur J Histochem. $2009 ; 48(3): 223-34$.
6. Bentzinger CF, Wang YX, Rudnicki MA. Building muscle: molecular regulation of myogenesis. Cold Spring Harb Perspect Biol. 2012 ; 4(2) : a008342.

7. Ferri P, Barbieri E, Burattini S, Guescini M, D'Emilio A, Biagiotti L, et al. Expression and subcellular localization of myogenic regulatory factors during the differentiation of skeletal muscle C2C12 myoblasts. J Cell Biochem. 2009; 108(6) : 1302-17.

8. Dedieu S, Mazères G, Cottin P, Brustis JJ. Involvement of myogenic regulator factors during fusion in cell line $\mathrm{C} 2 \mathrm{C} 12$. Int J Dev Biol. $2002 ; 46: 235-41$.

9. Wells L, Edwards KA, Bernstein SI. Myosin heavy chain isoforms regulate muscle function but not myofibril assembly. EMBO J. 1996 ; 15(17) : 4454-9.

10. Montesano A, Luzi L, Senesi P, Mazzocchi N, Terruzzi I. Resveratrol promotes myogenesis and hypertrophy in murine myoblasts. J Transl Med. 2013 ; 11(1) : 310.

11. Glass DJ. Signalling pathways that mediate skeletal muscle hypertrophy and atrophy. Nature Cell Biol. 2003 ; 5(2) : 87-90.

12. Glass DJ. Skeletal muscle hypertrophy and atrophy signaling pathways. Int J Biochem Cell Biol. 2005 ; 37(10) : 1974-84.

13. Kim CK, Kim M, Oh SD, Lee SM, Sun B, Choi GS, et al. Effects of Atractylodes macrocephala Koidzumi rhizome on 3T3-L1 adipogenesis and an animal model of obesity. J ethnopharmacol. $2011 ;$ 137(1) : 396-402.

14. Han Y, Jung HW, Park YK. The roots of Atractylodes japonica Koidzumi promote adipogenic differentiation via activation of the insulin signaling pathway in 3T3-L1 cells. BMC Complement Altern Med. 2012 ; 12(1) : 154.

15. Yeh TS, Hsu CC, Yang SC, Hsu MC, Liu JF. Angelica Sinensis promotes myotube hypertrophy through the $\mathrm{PI} 3 \mathrm{~K} / \mathrm{Akt} / \mathrm{mTOR}$ pathway. BMC Complement Altern Med. 2014 ; 14(1) : 144

16. Akhmedov D, Berdeaux R. The effects of obesity on skeletal muscle regeneration. Front Physiol. $2013 ; 4: 371$.

17. Pedersen BK, Febbraio MA. Muscles, exercise and obesity: skeletal muscle as a secretory organ. Nat Rev Endocrinol. 2012 ; 8(8) : 457-65.

18. Perry R, Rudnick MA. Molecular mechanisms regulating myogenic determination and differentiation. Front Biosci. $2000 ; 5$ : D750-67.

19. Rudnicki MA, Schnegelsberg PN, Stead RH, Braun T, Arnold $\mathrm{HH}$, Jaenisch R. MyoD or Myf-5 is required for the formation of skeletal muscle. Cell. 1993 ; 75(7) : 1351-9.

20. Wagatsuma A, Sakuma K. Mitochondria as a potential regulator of myogenesis. Sci World J. 2013 ; 2013 : 593267.

21. Duguez S, Féasson L, Denis C, Freyssenet D. Mitochondrial biogenesis during skeletal muscle regeneration. Am J Physiol Endocrinol Metab. 2002 ; 282(4) : E802-E9.

22. Williamson DL, Butler DC, Alway SE. AMPK regulation of 
proliferation and differentiation in $\mathrm{C} 2 \mathrm{C} 12$ culture models. FASEB J. 2007 ; 21(6) : A1205.

23. Pardo PS, Boriek AM. The physiological roles of Sirt 1 in skeletal muscle. Aging (Albany NY). $2011 ; 3(4)$ : 430-7.

24. Taulet N, Comunale F, Favard C, Charrasse S, Bodin S,
Gauthier-Rouvière C. N-cadherin/p120 catenin association at cell-cell contacts occurs in cholesterol-rich membrane domains and is required for RhoA activation and myogenesis. $\mathrm{J}$ Biol Chem. $2009 ; 284(34): 23137-45$. 